International Journal of

Culture and Religious

Studies

(IJCRS)

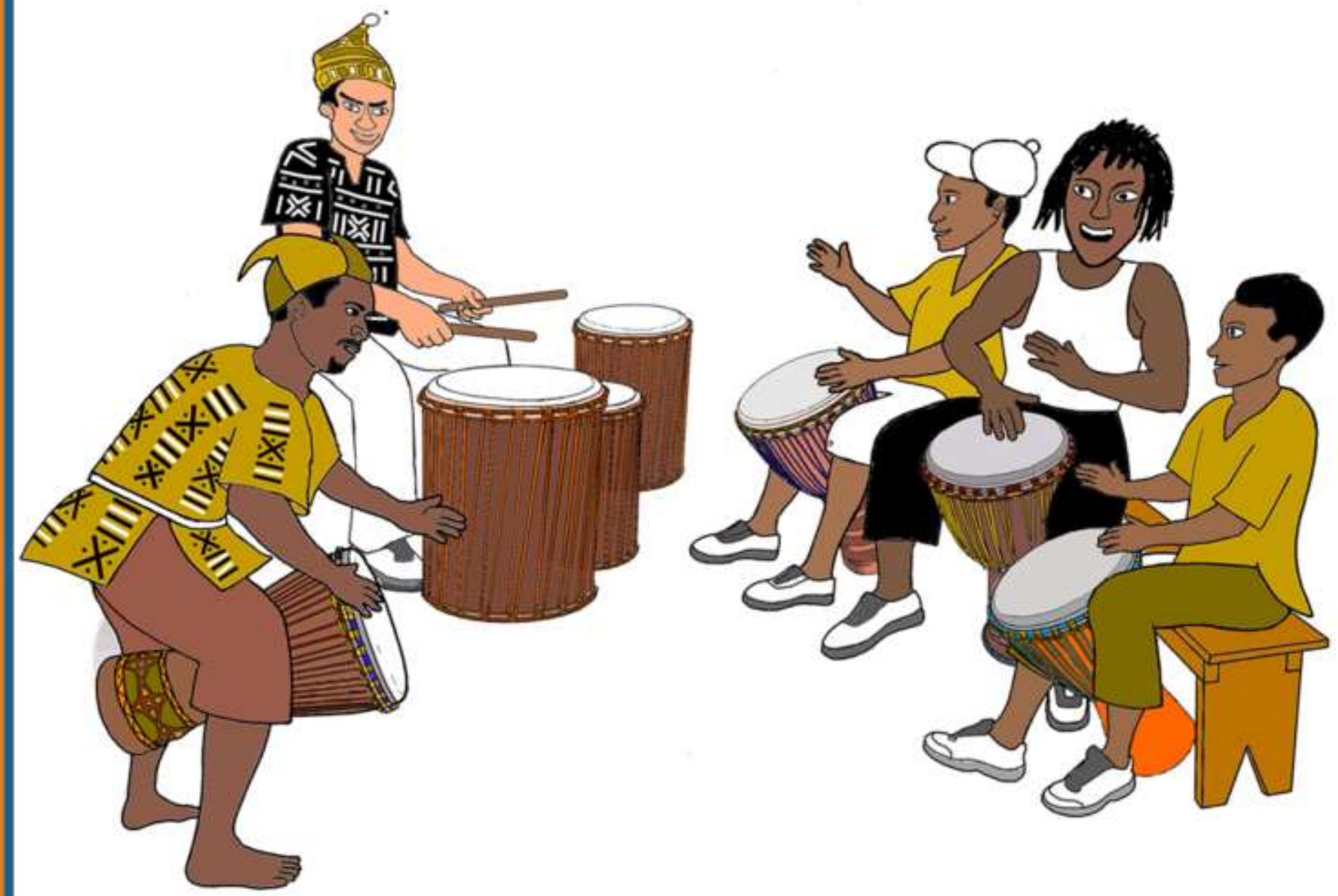




\title{
Philosophy of Religion and Religious Pluralism from Biblical Perspective and Their Implications for Christian Education
}

\author{
${ }^{1 *}$ Siwoku-Awi, Omotayo Foluke \\ Department Of French, University Of Ilorin \\ *Corresponding Author's E-mail : siwoku-awi.of@unilorin.edu.ng
}

\begin{abstract}
Purpose: Students of Christian Religious Studies should be encouraged to learn about other religions in order to enhance their personal conviction and be tolerant and competent in engaging in meaningful negotiation when mediating in crises. It is an exploratory research that has deployed resources from documents, media and personal interaction and inquiries. Religion is a cause of disunity, tribal disparity, ethnic cleansing and wars in most parts of the world. Religion has empowered some individuals to kill, maim, rape, enslave and self-impose on others. It has been mingled with politics in some countries like Iraq, Syria, Afghanistan, Middle East, most African countries and many others. The practice of religion has been used to discriminate against job seekers and in matters of welfare. It brings tremendous gains to some people while others are impoverished.

Methodology: Real life occurrences as published by the media of people who have been victims of religious intolerance, violence, psychological and sexual slavery. For instance, in the Middle East entire communities are eliminated by murder and rape of children and youths who are abducted to be subjected to indoctrination or kept as hostages until some money is paid on them. These destructive tendencies forestall development.

Findings: The findings are: A God-centered religion should emphasize divine qualities in the lives of believers. Compliance with the National Constitution of one's country is more beneficial than man-made tenets and laws that are of the least benefits to the general public or human progress and which cause dissension and do not necessarily reflect the nature of God, the Creator but that of an invisible personality that only forms a part of human imagination. Faith in God should be a reason to love fellow humans 1 John 4:20. Learning philosophy of religion is training in peaceful coexistence. Religion arouses intense emotions; therefore, it may not deploy rationality in fostering good human relations and respect of the rights of opponents.
\end{abstract}

Unique Contribution To Theory, Practice And Policy: This article contributes to contemporary realities by proposing that democratic governments should institute peace and order by enabling equal rights of worship, freedom of religion, of choice and of self-expression. The research leans heavily on the Bible and the claims of Jesus Christ, a fact of history, whose moral perfection, peaceful lifestyle, teaching and philosophy express values that are worthy of emulation for human development, progress and peace.

Key words: pluralism, philosophy of religion, Bible tenets, Islam, Ba 'hai, Buddhism 


\section{Introduction}

Religion is generally assumed to forge the identity of a people and community; however, contemporary societies are faced with myriads of ideologies, beliefs and philosophies that making a personal life choice should necessarily tolerate other points of view. Paradoxically, the practice of religion has been the major reason for civil unrests, insurgences and interethnic wars in most parts of the world, whereas it should have fostered peace and brotherhood. It is important that students of Christian Religious Studies get trained on these opposing world views in order to enhance their personal conviction and be able to defend their faith and for meaningful crises resolution. The zeal and intensity of hatred expressed by people of divergent religions and cultures leave no doubt that much personal profit is made from them. For some religionists, the rituals are sources of revenue and economic empowerment, like the mandatory pilgrimages to Saudi Arabia or Israel have been money spinning ventures for some people as well as the sales of faith items. For others, religion empowers them with the mandate to kill, maim, rape and enslave opposers.

Moreover, such tenets that encourage self-imposing on others only endorse the claim that they are for the gain of a particular set of people and not necessarily for the mental well-being and personal development of the target individuals. If any religion is based on faith in God, it should be for the collective benefit of individuals and their communities. Personal choices (philosophies) to respect human rights and maintain good interpersonal relationships, to be selfless and considerate of others are higher values than religious sentiments that cause people to hate and devalue others by discriminating against them. Disparaging beliefs, which individuals are very passionate about and that cause violent reprisals and suicide killings should be discouraged and discarded. The Constitution of a secular democratic society should give equal rights of worship.

\section{The Philosopher and philosophy of religion}

There are two key expressions in the topic: Philosophical and religious pluralism. The word philosophical is the adjective of philosophy, hence knowing what philosophy is should lead eventually to determining the quality of what is philosophical. The word 'philosophy' came from the Greek word 'Philo' which means to love wisdom. It is a way of perceiving and practically almost everybody expresses views about certain issues of life, or adopts a position in the midst of multiple ideas. These ideological choices may be termed personal convictions on the matters of interest. Expressions like "that is my personal philosophy on the matter? Or like "I like the politician's philosophy", are often heard or of a person's philosophy in the face of challenges but that is a stoic acceptance or anxious reaction when there is disappointment. Popkin, Richard H.; Avrum Stroll \& Kelly A. V. (1995 ix) in Philosophy Made Simple explain philosophy as:

As an evaluation or interpretation of what is important or meaningful in life this usage may be indicated in life by the story of two men who were drinking beer together. One of them held his glass to the light, scrutinized it thoughtfully, and then observed, 'Life is like a glass of beer.'

His companion looked up at the glass, turned to his friend, and asked, 'why is life a glass of beer?' 
How do I know, he answered, I'm not a philosopher? (p xii)

The quote connotes the purview that philosophy raises questions for which attempts are made to find answers. This makes it an intellectual, mental and tasking activity, from which a large number of people turn away. Meanwhile, some renowned philosophers have attempted to provide answers to germane issues of life like: the meaning and essence of life; the existence of God; economic matters; political practice; governance; life after death, problems of good and evil, and many more enigmas that cause psychological stress. From Socrates who is regarded as the Father of philosophy down to contemporary theorists like Bertrand Russell, their polemics of abstract ideas and matters have provided impetus for practical debates. Popkin et al. have this to say about the person of the philosopher:

Through careful critical examination he has tried to evaluate the information and beliefs we have about the universe at large, and the world of human affairs. From this investigation, the philosopher has attempted to work out some general, systematic, coherent and consistent picture of all that we know and think. (p xii)'

In essence, the philosopher provides food for thought by his/her insight, conjectures and analyses. Opinions about the universe, world order, traditional beliefs or scientific discoveries are based on verifiable personal experiences that the philosopher insists on subjecting to critical examination in order to determine if they can be adhered to. Socrates at his trial in 399 B.C. had contended that "the unexamined life was not worth living" ( $p$ xiv). The trend in popular cultures indicates that most people never take the time to contemplate the foundations and reasons for popular beliefs, religions and traditions and in particular if they have any general consistency or coherence or the goodness that is beneficial to humanity. Evans and Manis submit that

philosophy is a rational enterprise. Whatever else it may be, philosophy is a reflective activity; philosophy is a kind of thinking. Of course, not every kind of thinking will qualify as philosophical. No one would dignify one's thinking about what kind of toothpaste to use with the label "philosophy." The thinking we call philosophy is an unusually serious kind of thinking, directed to especially serious kinds of problems.

Certain kinds of questions seem to be asked by almost all human beings who have reached a certain level of reflectiveness. Who am I? What kind of a world do I live in? What is worth living for? These foundational questions have universal significance, and they properly inspire the deepest and most rigorous kind of thinking. Answers to them, especially when those answers are comprehensive and organized, are called "religious." Religious philosophy, then, is philosophical thinking which is religious in inspiration or direction ( $\mathrm{p} 21$ ) 
Philosophy as a discipline is not monolithic and is extensively articulated in myriads of human thoughts: religion, science, education, government, economy, origins of human life and the universe and so on. Philosophy has been a way of answering questions that emanate from these disciplines. For instance the ancient Greek philosophers attempted to verify the mythological claims about the activities of gods and spirits in the natural world and the claims about the origins of humans, yet it has been discovered that the versions of the origins of life are as many and varied as there are races, peoples, and tribes. Hence, there could not have been a monolithic explanation of the origins of humanity. Ancient philosophers challenged these beliefs and developed more defensible and well thought-out theories that are plausible and more acceptable. This means that the phenomena of human existence cannot be explained in a simplistic mode; therefore much tolerance is needed to accommodate other people's worldviews without compromising one's personal choices.

\section{What is Religious Pluralism?}

It is pertinent to explain the concept of religion. Religion may not just be a quest for the knowledge of the supreme or deities through a set of practices as submitted by Wotogbe-Weneka (2012 p 4) because there are some religions that discountenance the existence of deities.

But there are some recognized Religions of mankind which do not believe in God/gods as such, yet are considered religious enough. How then would one define Religion to be able to carry along those religions which believe in God/gods and those that do not or those theistic religions and non-theistic ones.

Religion connotes a sense of commitment to a cause or to an ideology. If defined from the theistic point of view the ontological assumption is that there is a God or some gods to whom the individual or a people defer. Josephine Soboyejo (2018) in her lecture notes on Philosophy of Religion submits the following definitions of religion:

Religion is the activity that appeals to all that is noblest, purest and loftiest in the human spirit; in essence it is a way of living to glorify a supreme being known as God, Gods, god, or gods, and God-gods. Sri Shantananda Saraswathi's definition goes thus:

Religions are a set of rules, which arise out of certain situations based upon the physical, intellectual, and emotional parts of human nature, the society, the nation and time. All such aspects come together in some special measure in a system given by some individual for the uplift and well-being of his people.

Emile Durkheim defines religion as:

A unified system of beliefs and practices which unite into one moral community called a church all those who adhere to them. 
A.C. Bouquet defines religion as a fixed relationship between the human self and some non-human entity, the sacred, the supernatural the self-existent, the absolute or simply, God.

Going by all the cited definitions, all religions defer to a Supreme Being, which make them theists. The atheistic concept of religion may be linked to this researcher's opinion that "Religion connotes a sense of commitment to a cause or to an idea, in which case there are some religions that are not theistic like Buddhism. In this wise, the idea of religious pluralism will therefore incorporate both theist and atheist conceptions of religion. Pluralism has developed from the diverse ways different peoples or individuals have conceived of the notion of God, gods or ideologies as the case may be.

According to Internet Encyclopedia of Philosophy

Religious Pluralism, broadly construed, is a response to the diversity of religious beliefs, practices and traditions that exist both in the contemporary world and throughout history.

This response can be deemed as philosophical or theological. Religious diversity can occur between particular religious traditions but also within them. Within a particular religion, pluralism will refer to sects and denominations. Christian denominations and Islamic sects fall within this category. Religious diversity has been categorized into three by Alan Race (1983) they are: exclusivist, inclusivity and pluralist. The exclusivist maintains that only one set of beliefs or practices can ultimately be true. A Christian exclusivist holds that Jesus is the Way the truth and the life and no one can get to heaven except through Him. John 14.6.

Even Christians of other denominations may be flawed when their beliefs conflict. For instance a group that holds strongly to baptism by immersion may object to another group that is less strict about it and prefers the sprinkling of water; or the practice of the Holy Communion; or of dressing styles etc. Inclusivity positions occupy a middle ground between exclusivist and pluralism. They recognize that more than one religious tradition can contain elements that are true and efficacious but there can only be one tradition that expresses ultimate truth. Pluralists argue that more than one religious practice can be partially or wholly true and correct. A pluralist position incorporates many religions and they are all equally good and effective.

Having clarified the terms it is important to note how pluralism started. Cultural and religious pluralism started from antiquity. In most societies of the antiquity people shared similar opinions on many issues; it was when philosophers started reasoning and questioning about cultural and religious practices that diversity of opinions became evident (Omoregbe, Joseph, 1993). In India or in African traditional religions where many gods are acknowledged and worshipped, pluralism is inherent in the practice of such religions, though they claim a pantheon of gods, there is a recognized hierarchy. Joshua Mark (22 February, 2011) in his article "Mesopotamia Religion" describes the disputes of the gods in the creation of the earth (https://www.worldhistory.org>Mesopotamia). In the ancient Mesopotamia, movements of traders as recorded in the Bible or some archeological or history books are reasons for the spread 
of new religions or ideas across the world in the antiquity. Pluralist opinions must have developed in this way, because the hallmark of pluralism was toleration.

In addition, the Egyptians must have despised the Hebrews for not worshipping their gods when they bitterly enslaved them. And when according to the Book of Exodus 20, Moses was called to deliver them God gave them the Ten Commandments, the first of which was "Thou shalt have no other gods beside Me". So Judaism never supported pluralism; indeed God instructed them to drive out of Canaan, the idol worshippers there so that they would not lure them into sin if they cohabited. Right down to the era of Christianity pluralism has not had a place in the authentic practice of those who believe in salvation through Jesus Christ.

The Greek and Roman religions would be called paganism and Greco-Roman mysteries in which a great number of deities were worshipped. Because the Roman Empire absorbed deities and cults of other peoples in order to promote social stability and its expansionist policy, religions and mysteries came from all the nations around. The Greeks introduced the cult of Apollo and other Greek myths. Mystery religions were imported from the Near East (Ptolemaic Egypt, Persia and Mesopotamia) The Romans cultivated international deities and encouraged the construction of temples, and shrines for those gods. It was an elaborate pluralistic and multi-religious setting, where monotheistic religions like Judaism posed difficulties, but the Roman Government conceded some exemptions though there were sometimes conflicts. Conflicts became tenser, when Christianity developed under the wings of Judaism and the exclusivist Christians claimed to be different, their faith was declared religio illicita.

Biblical position is very clear about the salvation plan of God as unique, incomparable and absolute. Exclusivist Christians rely on the following scriptures:

Acts 4:12 Neither is there salvation in any other. For there is none other name under heaven given among men, whereby we must be saved.

1Timothy 2.5 For there is one God, and one mediator between God and men, the man Christ Jesus.

John 14.6 Jesus saith unto him, I am the way, the truth and the life no man cometh unto the Father, but by me.

Acts 17.26 Forasmuch then as we are the offspring of God, we ought not to think that the Godhead is like unto gold, or silver, or stone, graven by art and by man's device.

Exodus 20.3 Thou shalt have no other gods before me.

Exodus 34. 14 For thou shalt worship no other god; for the LORD, whose name is Jealous is a jealous God.

Mark 12.32 And the scribe said unto him, Well, Master, thou hast said the truth: for there is one God; and there is none other but he. 
Isaiah 42.8 I am the LORD: that is my name: and my glory will I not give to another, neither my praise to graven images.

Inclusivity Christians hold a more compromising stance that there can be truth and salvific value in other religions. There are some Christians, who hold the view that there are some values in other religions and such are likely to incorporate these other views into their set of beliefs. This had given rise to syncretism within the Christian faith. John Macquarrie (1998), a twentieth century Anglican theologian (1998) wrote that there should be an end to proselytizing but that equally there should be no syncretism of the kind typified by the Baha'i movement (p.2). Macquarrie's stand implies that Christians do not have to evangelize but his injunction denounces the command of Jesus Christ after His resurrection in Matthew 28: 19-20 that the disciples should go all over the world to make disciples, howbeit by teaching and miracles and not necessarily by force. Macquerrie discussed nine founders of faith and put them on par, while claiming that they are all mediators between man and the divine; he wrote on Moses, Zoroaster, Lao-zu, Buddha, Confucius, Socrates, Krishna, Jesus and Muhammad. Incidentally, Macquerrie has been the most distinguished systematic theologian in Anglicanism. His reference to the Baha'i faith is very significant.

The Bahá'i faith developed in Persia; Bahá'ulláh was the founder and he urged the elimination of religious intolerance. He taught that God is one, and has manifested himself to humanity through several historic messengers. Bahá'ulláh taught that his followers, the Bahá'is, must associate with peoples of all religions, sharing the love of God in relations with them, whether this is reciprocated or not. He elaborated the concept of Progressive revelation, which means that God's will is revealed to mankind progressively as the mind matures and is better able to comprehend the purpose of God in creating humanity. In this view, God's word is revealed through a series of messengers: Abraham, Buddha, Krishna, Moses, Jesus, Muhammad, and Bahá'ulláh. There is also a respect for traditional religions. (Wikipedia, accessed 8 September, 2019). For the exclusivist Christian, equating other founders of religions with the Lord Jesus Christ is denouncing the divinity of the Messiah, the uniqueness of his sinless life, the vicarious death and the fact of the resurrection. Believers in Christ hold the view that $\mathrm{He}$ is the only Saviour, Who gives an experience that goes beyond mere compliance with religious laws and tenets. These personal experiences of being delivered from overpowering sins and being filled with the Holy Spirit are too real to be doused by motley of philosophies originated and developed by some smart minds.

The Buddhist Dalai Lama was reported to have asked "Don't all religions teach the same thing? Is it possible to unify them? Hence, in Buddhism there should be contact between religions; one should listen to and respect the doctrines professed by others. Beloved-of-the-Gods, King Piyadasi desires that all should be well-learned in the good doctrines of other faiths (Rock Edict Nb12 (S. Dhammika). People of different faiths should keep to the traditions. The Dalai Lama's speech cited below is very pertinent to this discussion and sums up religious tolerance, which is the fundamental principle for pluralism. He was quoted in Wikipedia (accessed 9 September 2019) as saying: 
Tibetan may prefer Islam, so he can follow it. Some Spanish prefer Buddhism; so follow it. But think about it carefully. Don't do it for fashion. Some people start as Christian; follow Islam, then Buddhism, then nothing.

In the United States I have seen people who embrace Buddhism and change their clothes! Like the New Age. They take something Hindu, something Buddhist, something, something... That is not healthy.

For individual practitioners, having one truth, one religion, is very important. Several truths, several religions, is contradictory.

I am Buddhist. Therefore, Buddhism is the only truth for me, the only religion. To my Christian friend, Christianity is the only truth, the only religion. To my Muslim friend, [Islam] is the only truth, the only religion. In the meantime, I respect and admire my Christian friend and my Muslim friend. If by unifying you mean mixing, that is impossible; useless.

The positions of Macquerrie and Dalai Lama are similar as they align with the principles of pluralism that people should make their choices, there is no need to cross-carpet, besides religions can co-exist as they are all equally important when they engage in human welfare and respect of human rights. It is no doubt self-contradictory to profess a religion and find possibilities in another; that is mixing religions according to Dalai Lama. These positions are at variance with the Biblical teaching which declares that human sin nature cannot make him/her relate to God. The barrier of sin can only be removed by the blood of Jesus (Hebrews 9:13-15). This declaration has to be announced to the world. On the other hand Hinduism is naturally pluralistic as a Rig Vedic hymn says "Truth is one, though all sages know it variously." God manifests as an incarnation and declares that all paths lead to him. "As people approach me, so I receive them. All paths lead to me." These claims are diametrically opposed to the Bible in which there is a remarkable coherence and consistence such that a section dovetails into another, and the whole stretch of it points to only Yahweh, the God of creation nullifying the possibilities of other gods. The presence of Yahweh is unique in the Bible and there cannot be any other God. Exodus: 20: $1-5$

Then God said, I am the Lord your God. I led you out of the land of Egypt where you were slaves. So you must obey these commands: You must not worship any other gods except me. You must not make any idols. Don't make any statues or pictures of anything up in the sky or of anything on the earth or of anything down in water. Don't worship or serve idols of any kind. Why? Because I, the Lord, am your God. I hate my people worshipping other gods. People who sin against me become my enemies. And I 
will punish those people. And I will punish their children, their grandchildren, and even their great-grandchildren.

Yahweh called out Abraham from among his pagan relations in order to give him a distinct experience of knowing a personal to whom he could relate. It is this real life experience that culminates in the provision of salvation through Jesus Christ.

\section{Atheism and Persecution of Religionists}

Atheism is defined as the denial of the existence of God/gods or a Supreme Being that can be called the Creator of the world. Some countries have been identified as typically atheist because of their indifference to the belief in the existence of God and their persecution of religionists. History tells us that during the Chinese Cultural Revolution of Mao Zedong (1893-1976), Christians were arrested, imprisoned, tortured and killed for their faith. The situation has not got better because Chinese Communist Party (CCP) is still seriously persecuting Christians who would not renounce the Bible (www.heritage.org/religious-liberty/commentary/religiousfreedom-whats-at-stake-if-we-lose-it). Reports have it that Muslims are also currently subjected to the worst abuses in China, and Christians are being detained at secretive "brainwashing camps" as a crackdown on religion. Individuals are arrested from their house church that operates outside of state approval and are subjected to verbal and physical abuse. Olivia Enos recounting the ordeal of Li Yuese writes

Imprisoned in a windowless room without ventilation, $\mathrm{Li}$ was subjected to verbal and physical abuse. United Front officials use intimidation, threats, and beatings to force detainees to renounce their faith. The repression was so brutal that Li testified, "After you've been in there a week, death starts to look better than staying there. "At his release, Li was in very poor health. He remains haunted by his experience.

This report was corroborated by Dr Ewelina U. Ochab, who reported in Forbes (https://www.forbes.com>2021/05/05) that "authorities in China are detaining Christians in secretive, mobile 'transformation' facilities to make them renounce their faith." The CCP believes that the independent house churches are a threat to the state; therefore Xi Jinping's policy of "Sinicization" has been construed to force religionists to conform to its political goal. Enos added:

The CCP's persecution of Christians has also involved demolishing churches and arresting leaders like Pastor Wang Yi of Early Rain Covenant Church, who was sentenced to nine years in prison in 2019.

According to the Voice of the Martyrs (persecution.com/global>china) about 130 million Chinese are Christians and only 30 million of them are affiliated with the Three-Self Patriotic Movement (TSPM) which is the only recognized church but it is statecontrolled and those who would not comply with the restrictive religious regulations are seriously persecuted. It is illegal to disciple anyone younger than 18 years and more than 170 million facial 
recognition cameras have been installed in or near churches in order to identify those who attend worship services. Children and grandchildren of Christians are denied schooling and false allegations are made against Christians. Bibles are not available in significant (https://www.churchtimes.co.uk>news) numbers but small quantities are sold by the TSPM (Three-Self Patriotic Movement) bookstores and online Bible sales have been prohibited. The TSPM is State regulated and controlled, having been founded by State Administration of Religious Affairs. Government puts in place a machinery of intense monitoring and violations of human rights such that both young and old people may not freely practice their beliefs. Rebecca Paveley (19 February, 2021) in the article titled "Persecution of Christians Predicted to Worsen in China"

Persecution of Christians is as severe now as during Mao's Cultural Revolution, and is expected to worsen in the coming year, owing to growing intolerance in Hong Kong and increasing digital surveillance in churches, a charity has warned.

Chinese Government under the pretext of COVID-19 keeps a permanent watch over churches through digital surveillance.

Dr Ewelina U. Ochab states in her article "Are Christians in China Next in Line For 'ReEducation'?

While allegations are yet to be investigated, they add to the evergrowing evidence of the deteriorating treatment of religious groups in China. Recent report suggested that Uyghurs have been subjected to killings, torture and abuse, rape and sexual violence, forced labor, forced abortions, forced sterilizations and much more. Other reports suggest that Falun Gong practitioners are subjected to forced organ harvesting. Christians are subject to various methods of discrimination and persecution in China. Christians often complain of the closures of churches, bans on the sale of bibles online, the removal of crosses and the arrest of priests and worshipers. Reports also suggests there are plans to "contextualize" the Bible to make it more "culturally acceptable" and for Christian preaching to be adapted to include the core values of socialism.

The Observer in a headline "In China, they're closing churches, jailing pastors - and even rewriting scripture". The China's Communist Party assumes that a state translation of the Bible will establish a correct understanding of the text. Reporting for The Observer Lily Kuo wrote from Chengdu (13 Jan 2019) (www.theguardian.com/world/) that the crackdown on the Early Rain Church has been the worst since the Cultural Revolution when Mao Zedong vowed to eradicate religion. On the other hand Lily Kuo cited a Government official as saying:

The goal of the crackdown is not to eradicate religions, "said Ying Fuk Tsang, director of the Christian Study Centre on Chinese Religion and Culture at the University of Hong Kong. "President 
$\mathrm{Xi}$ Jinping is trying to establish a new order on religion, suppressing its blistering development. [The government] aims to regulate the 'religious market's a whole.

Church leaders might have been inspired by the democratizing role the church played in Eastern Europe as several of most active human rights lawyers are Christians. Lily Kuo reported: "They have come to see the political potential of Christianity as a force for change. What really makes the government nervous is Christianity's claim to universal rights and values."

Other minority groups, Buddhists and the Uyghur (Uighur) Muslims are subject to similar treatment of intimidation so that they could be reeducated to renounce their faith. The Buddhists persecution was initiated by Tang Emperor Wuzong during the Huichang era (841-845). He intended appropriating war funds from the wealth that had been accumulated in the Buddhist monasteries. But other religions such as Zoroastrianism, Nestorian Christianity and Manichaeism were also persecuted. Alexandra Ma (Aug 3 2019) in the article "Jailing Muslims, burning Bibles, and forcing monks to wave the national flag: How Xi Jinping is attacking religion in China" submits that the officially atheist Chinese Communist Party disapproves of all kinds of grassroots organizations as they are seen to undermine its grip on power. It is evident that China is waging an unprecedented war on religion. Alexandra Ma states (https://www.businessinsider.com>howxi-jinping-is-attacking-religion-in-china) that :

Over the past year alone, China has detained Muslim for showing their faith, forced Buddhists to pledge allegiance to the ruling Communist Party, and coerced Christian churches to take down their crosses or shut down.

Five religious organizations have been allowed to exist in China: Buddhism, Taoism, Islam, Protestantism and Catholicism, but the 'sinicization' of religion keeps them in check, while the state controls their personnel, publications, and finances. World Atlas defines 'sinicization' as "the overall influence of elements of Chinese culture on other places in the world." It is a policy that seeks to bring people who are not of Chinese descent under the influence of the Chinese culture (www.worldatlas.com/articles/sinicization).

Another historical figure, who carried out an unprecedented persecution and genocide, was the German dictator, Adolph Hitler, who persecuted and killed about 6 million Jews in Concentration Camps (like the Chinese now do), and million others whom he and his followers deemed Untermenschen (subhumans) or socially undesirable. According to Holocaust Encyclopedia the concept of Germanic peoples as the "master race" developed from the legend of the mythical Aryan race which never really existed but was propagated by the Nazis in order to glorify the German people who thereafter deemed the Jewish people, Black people, Roma and some others as "non-Aryans" and inferior. Adolph Hitler and his acolytes promoted this concept and radicalized the myth of the existence of an "Aryan race" to fit their political ideology. These claims and the colonization of Black people underpinned the notion of White superiority".

In the article titled: "Antisemitism in History: Racial Antisemitism, 1875-1945", in the Holocaust Encyclopedia, Nazi racial discrimination against the Jews might be because of Jewish dominance 
in economy and in most domains and their mixed marriages must be a ploy to dominate the world and the probability that it could be for the inferiority complex that the Nazis felt because the Jews claimed that they were God's chosen people. If they considered the Jews as inferior they who felt superior should have let them be, after all a superior entity has nothing to lose. On the contrary they had gnawing sense of inferiority as they regarded the Jews as their mortal enemies because of the European Jewry envious heritage (Holocaust Encyclopedia). They did not stop being Jews if they became Christians, hence, it was a racial issue stepped in religious claims. Following the defeat of the Germans in World War 1 and their country's subsequent economic chaos, many Germans saw the Jews as villains (David G. Myers, 2010, p 325). Myers submits that: "Long before Hitler came to power, one German leader explained: "The Jew is just convenient...If there were no Jews, the anti-Semites would have to invent." Some people must be treated like scapegoat. It was a case of displaced aggression.

Working with a British social psychologist, Henri Tajfel, Turner, a Polish native family who lost family and friends in the Holocaust devoted much of his time studying ethnic hatred from which he postulated the social identity theory, (Myers, p 326) wherein people put themselves into categories, the in-group syndrome and which implies definition by gender, race, religion, marital status, sexual orientation, or academic achievement. The in-group bias is also a basis for competition with the out-groups. These are recent psychological theories that explained some of the reasons for the Holocaust. Religious sects like the Jehovah's witnesses were persecuted, they willed in large numbers with those who the Nazis considered pollutants like, the asocial, homosexuals, the mentally sick or Polish men who slept with German women and therefore defiled the German race (Holocaust Encyclopedia).

The exclusivist teaching and beliefs of Christians make them victims today just like those who sit on the fence and believe nothing. It only implies that there are some weapon-happy and blood thirsty individuals, who would rather see people die so as to fulfill and satisfy their own cause. There is no doubt that there is general apathy and societal values have changed leaving out the fear of God, the tenets of religions and moral teaching, therefore the infallibility of God and His word have been queried.

\section{The position of Islam on Pluralism and Persecution of Unbelievers}

It is a paradox that Muslims are persecuted where they are in the minority and they on the other hand initiate the persecution of minority groups in their midst or self-impose on larger groups. Though Islam might have encouraged pluralism according to some passages of the Quran, the situation in the modern time is contradictory; making religious pluralism controversial. The hardline Islamists, who clamor for Islamic states through jihads and suicide bombings that cause devastation and destruction of properties; who maim and kill the innocent and weak in the society have probably not read or have misunderstood the passages of the Quran cited below in which Muslims have been enjoined to remain steadfast to Islam and not to yield to the vain desires of other religions and unbelievers yet they should tolerate them. Below are a few references to the Quran. It must be stated that the present world situation of intense drive for Islamic State has inspired a lot of interest in the Islamic religion and its claims as cited below from the Wikipedia. 
In several Surah Quran asks Muslims to remain steadfast with Islam, and not yield to the vain desires of other religions and unbelievers. These versess have been interpreted to imply pluralism in religions. For example, Surah Al-Maidah verses 47 through 49 state:

Let the people of the Gospel judge by what Allah hath revealed therein. If any do fail to judge by the light of what Allah hath revealed, they are no better than those who rebel. To thee We sent the Scripture in truth, confirming the scripture that came before it, and guarding it in safety: so judge between them by what Allah hath revealed, and follow not their vain desires, diverging from the Truth that hath come to thee. To each among you have we prescribed a law and an open way. If Allah had so willed, He would have made you a single people, but His plan is to test you in what He hath given you: so strive as in a race in all virtues. The goal of you all is to Allah; it is He that will show you the truth of the matters in which ye dispute; And this (He commands): Judge thou between them by what Allah hath revealed, and follow not their vain desires, but beware of them lest they beguile thee from any of that (teaching) which Allah hath sent down to thee. And if they turn away, be assured that for some of their crime it is Allah's purpose to punish them. And truly most men are rebellious. (Quran 5:4749)

If the writer of the Quran does not condemn but prioritizes the Scripture that came before it, the Gospel of Jesus Christ (that being the only Gospel), as stated above, it becomes difficult to understand the rationale behind giving people the only option of Islam and killing those who do not subscribe to it as commanded in some other parts of the Quran. Its relevance must then be weighed against the numerous losses of life and gross wickedness that is attached to it. Lives and properties are being lost to the agitators of the Islamic States that are threatening to take over the world. It is a real problem for everyone, political leaders and philosophers of religion, who do critical thinking in order to develop ways of solving such problems.

Surah Al-E-Imran verses 62 through 66 (Wikipedia):

This is the true account: There is no god except Allah; and AllahHe is indeed the Exalted in Power, the Wise. But if they turn back, Allah hath full knowledge of those who do mischief. Say: "O People of the Book! come to common terms as between us and you: That we worship none but Allah; that we associate no partners with him; that we erect not, from among ourselves, Lords and patrons other than Allah." If then they turn back, say ye: "Bear witness that we at least are Muslims bowing to Allah's Will. Ye People of the Book! Why dispute ye about Abraham, when the Law and the 
Gospel Were not revealed Till after him? Have ye no understanding? Ah! Ye are those who fell to disputing even in matters of which ye had some knowledge! but why dispute ye in matters of which ye have no knowledge? It is Allah Who knows, and ye who know not! (Quran 3:62-66)

There is apparently no room for other religions as cited above. There is a direct attack on the set of people called the People of the Book, who must have been Christians and were probably being persuaded to accept the Quran and worship only Allah. There is an evident contradiction in that if the first text were true and that credence was given to the older authentic Scripture, the Bible, called the Book in the Quran, then why do they condemn the beliefs, lifestyle, stance and practices of the People of the Book (the Christians)? It means there had erstwhile been a personality clash and lives should never have been destroyed in defense of a nebulous cause or any humanly designed ideology, because God holds human lives sacred in the Holy Scripture to which the text referred.

The early Christians must have erred as Church history narrates how they deviated from the Christ-like life, allowed divisions and contentions on various matters that did not prioritize the salvation of the soul and deliverance from sin, the reason for the death and resurrection of Jesus Christ. Rather they developed traditions that made the church lukewarm. For instance the epistles of Paul to the Corinthians reflect the divisions that he condemned as carnality and immaturity. In addition, the disputes referred to were the excuses by Jihadists for overrunning the Christian nations that stretched through all of Turkey to Saudi Arabia, nations which were originally Christian states.

Several verses of the Quran state that Islam rejects religious pluralism. For example, Surah AlTawba verse 1 through 5 seems to command the Muslim to slay the pagans (as stated in verse 9.5 called the 'sword verse') :

A (declaration) of immunity from Allah and His Messenger, to those of the Pagans with whom ye have contracted mutual alliances:- Go ye, then, for four months, backwards and forwards, (as ye will), throughout the land, but know ye that ye cannot frustrate Allah (by your falsehood) but that Allah will cover with shame those who reject Him. And an announcement from Allah and His Messenger, to the people (assembled) on the day of the Great Pilgrimage,- that Allah and His Messenger dissolve (treaty) obligations with the Pagans. If then, ye repent, it were best for you; but if ye turn away, know ye that ye cannot frustrate Allah. And proclaim a grievous penalty to those who reject Faith. But when the forbidden months are past, then fight and slay the Pagans wherever ye find them, seize them, beleaguer them, and lie in wait for them in every stratagem of war; but if they repent, and establish regular prayers and practise regular charity, then open the way for them: for Allah is Oft-forgiving, Most Merciful. (Quran 9:1-5) 
International Journal of Culture and Religious Studies

Vol. 2, Issue No. 1, pp 45- 78, 2021

WWW.carijournals.org

However, this verse is explained thus.

Hostilities were frozen for a three-month period during which the Arabs pledged not to wage war. Prophet Muhammad was inspired to use this period to encourage the combatants to join the Muslim ranks or, if they chose, to leave the area that was under Muslims rule; however, if they were to resume hostilities, then the Muslims would fight back until victorious. One is inspired to note that even in this context of war, the verse concludes by emphasizing the divine attributes of mercy and forgiveness. To minimize hostilities, the Qur'an ordered Muslims to grant asylum to anyone, even an enemy, who sought refuge. Asylum would be granted according to the customs of chivalry; the person would be told the message of the Qur'an but not coerced into accepting that message. Thereafter, he or she would be escorted to safety regardless of his or her religion. (9:6).

(Template: Cite Hathout, Jihad vs. Terrorism; US Multimedia Vera International, 2002, pp.5253)

The text specifically mentions pagans, which may simply be those who worshipped idols as gods. This term has now been expanded to mean any one outside the Islamic fold and who does not comply with the codes including Christians who were originally excluded from the massacre. The anthropomorphic idea of frustrating Allah is inconceivable as the justification for mass killing; humans get frustrated and exhibit displaced aggression but if the Almighty is regarded as merciful and just then there is evidently a contradiction that He would not forgive the penitent sinner or the striving righteous believer. Insisting on modes and patterns without inner penitence encourages hypocrisy particularly when conformity is to please humans and gain their favour. In short, the Omniscience and Omnipotence of the Supreme Being are underrated.

Conceiving of the Creator in human epithets is equally a Biblical doctrine as Jesus Christ is described as the perfect image of God while He also personally claimed to be one with the Father (John 17:21). In Colossians 1: 15-17, it is stated:

Who is the image of the invisible God, the firstborn of every creature: For by him were all things created, that are in heaven, and that are in earth, visible and invisible, whether they be thrones, or dominions, or principalities, or powers: all things were created by him and for him: And he is before all things, and by him all things consist.

The Separation of the Chosen Israelites to God and the Killing of Idolaters

Questions may equally be asked about the numerous killings and genocides recorded in the Bible. It must be added that the Old Testament Scripture stated similar routing and elimination of idolatrous nations because they did not acknowledge the Living God, Yahweh as their Creator (Deuteronomy 7: 1-7). 
When the Lord your God brings you into the land which you are entering to possess and has plucked away many nations before you, the Hittites, and the Girgashites, the Amorites, the Canaanites, the Perizzites, the Hivites, and the Jebusites, seven nations greater and mightier than you, And when the Lord your God gives them over to you and you smite them, then you must utterly destroy them. You shall make no covenant with them, or show mercy to them. You shall not make marriages with them; your daughter you shall not give to his son nor shall you take his daughter for your son, For they will turn away your sons from following Me, that they may serve other gods; so will the anger of the Lord be kindled against you and He will destroy you quickly. But thus you shall break down their altars and dash in pieces their pillars and hew down their Asherim [symbols of the goddess Asherah] and burn their graven images with fire. For you are a holy and set-apart people to the Lord your God; the Lord your God has chosen you to be a special people to Himself out of all the peoples on the face of the earth. The Lord did not set His love upon you and choose you because you were more in number than any other people, for you were more in number than any other people, for you were the fewest of all people (Amplified Version).

God had asked the people of Israel to clear the land of the pagans who were there as an act of judgment on the people, who worshipped idols and made their children pass through fire in the worship of Molech; they were not to strike an agreement with them; they should not take them as wives or husbands; their shrines and groves should be destroyed. In Jeremiah 51:20 God called the people of Israel His battle-axe and weapons of war to repay the evils of pagan nations. Finis Jennings Dake (1979) explained the apparent ruthless judgment of God:

The idea of showing no mercy was not cruel any more than the justice of a judge who tries and condemns a criminal (p 206).

In Leviticus 18: 1-30 God detailed out the sins of the surrounding nations to be avoided by His people because they were reasons that He ordered that they should be exterminated. Some of the sins are overlooked today but they were crucial in the purification of the people. Such sins were: incest, which is having sex with a near relative, one's child, father, mother, aunt, uncle sister, cousin, father-in-law, mother-in-law; adultery; idolatry; human sacrifice as in child dedication to the abominable gods, Molech/ Chemosh of Amun-Ra in which children were made to pass through fire; homosexuality and bestiality. God condemned the descendants of Lot, Abraham's nephew who were born as a result of incest with his daughters after his wife became a pillar of salt as she attempted to go back while they fled from Sodom and Gomorrah (Genesis 19).

In the Book of Deuteronomy the children, products of Lot's incest had become large nations called Ammonites and Moabites but God's standard could never be compromised, even though 
they were descendants of Lot, whom He spared from annihilations. Deuteronomy 23: 3-8 God delivered judgment and gave specific instructions about them:

An Ammonite or a Moabite shall not enter into the congregation of the Lord; even to their tenth generation their descendants shall not enter into the assembly of the Lord forever, Because they did not meet you with food and water on the way when you came forth out of Egypt, and because they hired Balaam son of Beor of Pethor of Mesopotamia against you to curse you. Nevertheless, the Lord your God would not listen to Balaam, but the Lord your God turned the curse into a blessing to you, because the Lord your God loves you. You shall not seek their peace or their prosperity all your days forever. You shall not abhor an Edomite, for he is your brother [Esau's descendant]. You shall not abhor an Egyptian, because you were a stranger and temporary resident in his land. Their children may enter into the congregation of the Lord in their third generation (Amplified Version).

The above text has been cited to highlight the reasons that God gave for the separation of the Israelites from the Moabites and Ammonites, they were because of their idol worship, hatred for God's people and plot to destroy not only the bodies of the Israelites but their souls. For every instruction given to them to destroy any people God had a purpose. The same Moabites were desperate to make Israel sin so that they would lose favour with God, therefore, they got into their private life and lured them into the deadly sin. Number 25: 1-5

Israel settled down and remained in Shittim and the people began to play the harlot with the daughters of Mob, who invited the Israelites to the sacrifices of their gods, and they ate and bowed down to Moab's gods. So Israel joined himself to the god Baal of Peor. And the Lord said to Moses, Take all the leaders or chiefs of the people, and hand them in the sun after killing them, that the fierce anger of the Lord may turn way from Israel. And Moses said to the judges of Israel, Each one of you slay his men who joined themselves to Baal of Peor.

Another set of people that God was angry with were the Amalekites and He commanded the people of Israel to eliminate them. Balaam, who had been paid by Balak, king of Moab to curse the people of Israel, blessed them instead and prophesied the destruction of the Amalekites. In Deuteronomy 25: 17-19 God commanded vengeance:

Remember what Amalek did to you on the way when you had come forth from Egypt. How he did not fear God, but when you were faint and weary he attacked you along the way and cut off all the stragglers at your rear. Therefore when the Lord your God has 
given you rest from all your enemies round about in the land which the Lord your God gives you to possess as an inheritance, you shall blot out the remembrance of Amalek from under the heavens; you must not forget (AMP).

The Amalekites killed the people when they were vulnerable and tired from the long trekking. They would have been mostly children and women. They ought to have demonstrated sympathy. God had chosen the people of Israel to communicate His laws and standards therefore the people who violated Godly principles were eliminated so that the people He had chosen would know how unpardonable some sins were and should be completely avoided. They were equally punished when they sinned. In Numbers 14: 11-29

And the Lord said to Moses, How long will this people provoke (spurn, despise) Me? And how long will it be before they believe $\mathrm{Me}$ [trusting in, relying on, clinging to Me], for all the signs which I have performed among them? [...] Tell them, As I live, says the Lord, what you have said in My hearing I will do to you. Your dead bodies shall fall in this wilderness - of all who were numbered of you, from twenty years old and upward, who have murmured against Me (Amplified Version).

A similar case was recorded in Numbers 21: 5-9 when the people of Israel complained and murmured against God. In Numbers 25: 1-9, about 24,000 Israelites were killed by a plague because they disobeyed by committing adultery with their unbelieving neighbours and took part in their idol worship. God did not spare His people whenever they compromised they would be defeated and killed in battle.

God had a purpose for punishing people by death; it was often to denounce and prevent the spread of evil and wicked precedence and to lay the principles of faith and obedience to Him. Not all pagans and unbelievers were killed in the Old Testament as cited in the case of the Egyptians who for a while were hospitable to the Israelites. Even though they were pagans, if they repented and accepted Yahweh they could be allowed into the congregation of God's people. It is a different emphasis in the New Testament when God fulfilled the promise of salvation for all nations through Jesus Christ which He had made to Abraham. Genesis 12:3

And I will bless those bless you [who confer prosperity or happiness upon you] and curse him who curses or uses insolent language toward you; in you will all the families and kindred of the earth be blessed [and by you they will bless themselves] (Amplified Version).

God told them in the wilderness that He led them out of slavery in Egypt in order to make them His holy people and fulfill the salvation of the world through them. In Deuteronomy 7:7-10, He is revealed as the Jehovah the Eternal God (Yahweh); Elohim the Creator; the faithful El (the Almighty, the Strong One). He keeps agreement with their forefathers; he shows mercy and love to those who keep His laws. He shows mercy to those who keep His commandments to eternal 
International Journal of Culture and Religious Studies

Vol. 2, Issue No. 1, pp 45- 78, 2021

$\underline{\text { www.carijournals.org }}$

generations. He repays those who hate Him and do not keep His commandments, in a way that they will personally know that their judgment is from God. He could only have justified using them for the salvation of sinners if they were holy and because no human is holy the Israelites fell short of God's glory and purpose for them and have been put in the category of sinners who must be saved through Jesus Christ (Romans 3:23 and Romans 6:23). No human deserves eternal life; humans merit hell because of the sin nature and their perpetual wickedness. Jesus Christ alone procures liberty from the sin natures and gives it freely to all who believe. Sin is of universal effects and consequences as daily news reports in some parts of the world are replete with information about crimes.

\section{Contemporary Islamic Terrorism}

People are now killed indiscriminately, with little regard for their religious leaning or their distinctive sinless lives, whereas those who claim to fight for God are rapists, armed bandits, robbers and lawless outcasts. It is worthwhile to appraise the relevance of any religion that orchestrates human development and not necessarily human elimination. But some ideologies and religious groups would do so in order to eradicate existing social and political order; it is definitely not sophistication to kill babies, children, women and the elderly, which is the case now. Whole villages are completely razed down and the people that are often killed are Christians, who also had done no wrong but to declare and live according to their faith in Christ. Life applications of the tenets of a religion, as well as their benefits to humankind, should be progressive and given recognition.

The BBC's report on modern Jihadism (11 December 2014) submits that Jihadists deem the fights and killings as the only way to restore God's rule on Earth or the Umma. The campaigns for creation of the Islamic States started in the late 1970s on the promptings of a booklet entitled AlFarida Al-Ghaiba (The Neglected Duty) by Mohammed Abdul Salam Faraj in which he advocated a physical struggle with the external forces rather than concentrate on personal inner self. He declared the Muslim regimes as enemies. Faraj's al-jihad group assassinated Anwar Sadat of Egypt in 1981. The crackdown on the Egyptian Jihadists forced them to flee to Afghanistan, where there was an on-going resistance to the Soviet Union invasion. In the 1990s Osama Bin Laden created Jihad and the name of his group is al-Qaeda - which means "the base" in Arabic. He created a base for Jihadists and fighters -Mujahideen in Afghanistan. They would later aid fellow Muslims in countries like Bosnia, Tajikistan and Chechnya to fight their non-Muslim compatriots.

In 1998, the Islamic movement called "World Islamic Front for Jihad against the Jews and the Crusaders" was formed by the combined effort of the Egyptian Mujahideen and al- Qaeda. Bin Laden and Ayman al Zawahiri signed a declaration of total war against the USA. Afterwards they bombed the American embassies in Kenya and Tanzania. On 11 September, 2001, some al-Qaeda Jihadists hijacked four airplanes to attack the American Twin Towers, killing about three thousand people. Similar attacks were carried out across the world by the Jihadists that had been trained by the group. The attacks included Bali in 2002, Casablanca in 2003, Madrid in 2004, and London and Amman in 2005. Sequel to the US invasion of Iraq produced new Jihadists. The 
International Journal of Culture and Religious Studies

Vol. 2, Issue No. 1, pp 45- 78, 2021

$\underline{\text { www.carijournals.org }}$

American effort to broker peace and foster respect of human rights and democracy in some parts of the world resulted in dissident opposition and reprisal by Islamic Fundamentalists.

The Jordanian militant, Abu Musab al-Zarqawi, formed the al-Qaeda in Iraq (AQI). Brutal and very violent attacks were carried out in Iraq and these were often videotaped, including the gory scene of beheading their victims. Many offshoots of al-Qaeda were created in various parts of the world: Arabian Peninsula (AQAP), Algerian Salafist Group for Preaching and Combat (GSPC), Islamic Maghreb (AQIM) and Somali jihadist group, al-Shabab. All these were violent groups whose political interests to rule completely obliterated the spirituality of living a pure life in the service of God and humanity. Rather than create the much needed peace, human development and progress, the Jihadists leave behind the tales of mass killings, arson with personal moral degradation of rape, citing BBC " summary killings, torture, amputations, ethno-sectarian attacks, and the rape and sexual slavery of women and girls". According to BBC reports more than six hundred inmates of Badoush prison, mainly Shia Muslims were summarily killed by the IS https://www.bbc.com/news/world-middle-east-57468594

More than 200 mass graves containing the remains of up to 12,000 people have so far been discovered in Iraq, according to the United Nations, which has concluded that IS committed acts that may amount to war crimes, crimes against humanity and genocide.

The IS conquered a part of Iraq and controlled the stretch of land of a surface area of 88,000 sq $\mathrm{km}$ (34,000 sq miles) from eastern Iraq to western Syria and imposed its brutal rule on almost eight million people. The BBC in reference to the Office of United Nations High Commissioner for Human Rights states:

militants took over Badoush prison on the morning of 10 June 2014 - the day they overran Mosul and sent shockwaves around the world. The more than 3,000 inmates at the prison were separated into groups according to their ethnic or religious affiliation. Sunnis were freed, while more than 600 others, mainly Shia, were loaded on trucks, driven to a ravine in an isolated stretch of desert about $2 \mathrm{~km}$ (1.2 miles) away, and shot one by one by militants.

The Islamic State in Iraq and the Levant (ISIL) was alleged to have committed a lot of atrocities and violations of human rights as reported by the Office of the UN High Commissioner for Human Rights (https://digitallibrary.un.org/record/791021?ln=en). They killed and abducted large numbers of people groups like the Yezidis, the Shias, the Shabak community, Turkmen, SabeaMandeans, Kaka'e, Kurds and Christians who would normally be spared for being "People of the Book." Many were forced to renounce their faith.

West Africa and Central Africa are presently under a siege of Islamic State militants. Linnete Bahati and Driss El-Bay of BBC monitoring, in their report on the collaboration of Allied Democratic Forces (ADF) and Islamic State (IS) in Central Africa reported that the Ugandan strongman, Idi Amin was the founder of the political group which toppled the government of Yoweri Museveni and had previously accused his government of persecuting Muslims. The ADF 
was defeated in 2001 and thereafter it relocated to the North Kivu of DR Congo and would resurface in 2014 and has since been unleashing terror on the Central African Republic. At the moment according to the BBC, Musa Seka Baluku pledged allegiance to IS, now operating as Islamic State Central African Province (Iswap) and he announced in September, 2020 that

"At present, we are a province, the Central African Province, which is one of many provinces that make up the Islamic State," he said.

Christians who constitute the majority of the population have been targeted in the deadliest attacks of the Iscap while it taunts the government of the DR Congo for its failure in protecting the victims from its devastating attacks. Linnete Bahati and Driss El-Bay report:

According to the UN's refugee agency, the UNHCR, the ADF has killed about 200 civilians and displaced nearly 40,000 others in Beni since January 2021. The rebel group also targets government and UN troops.

Similar concerns emerged in the West African sub-region where the Islamic State West Africa Province (Iswap). As expressed by Frank Gardner, BBC security correspondent the Islamic State carnages may be moving from the Middle East to make Africa the epicenter of Jihadist violence.

According to the Global Terrorism Index published on 25 November, the "centre of gravity" for the Islamic State group IS has moved away from the Middle East to Africa and to some extent South Asia, with total deaths by IS in sub-Saharan Africa up by $67 \%$ over last year.

"Africa is going to be the battleground of jihad for the next 20 years and it's going to replace the Middle East"

"West Africa", says ambassador Sales, "is a perfect storm, with nation states that don't control their territories, commit abuses by their forces, and have porous borders".

The Sahel countries: Mali, Chad, Burkina Faso, Niger and Mauritania are the hardest hit because of poverty, corruption, drought because of proximity to the Sahara desert and porosity of their borders. All the countries have suffered attacks at some point. Nigeria, south of the Sahel has had a lot of attacks from the Boko Haram insurgents and since the group pledged allegiance to the Islamic State in 2015 it has intensified its carnage in the sub-region. Gardner (BBC) wrote:

Nigeria has suffered some of the worst jihadist attacks in the region, with the government struggling to control the north-east of the country where the Boko Haram movement evolved.

According to the Global Terrorism Index, Boko Haram has been responsible for over "37,500 combat-related deaths and over 19,000 deaths from terrorism since 2011, mainly in Nigeria" but also neighbouring countries. 
The report points out that in 2019 "sub-Saharan Africa recorded the largest number of ISIS-related terrorism deaths at 982, or 41 per cent of the total".

The rivalry among the Jihadists: al-Qaeda, Al-Shabab and IS has also compounded the trouble in the West African region, they compete on the extent of violence and destruction of lives and properties as indices of their success. Most parts of Africa have experienced Islamic insurgency: Algeria, Libya, Tunisia, Somalia, Kenya, Uganda, Mozambique, Ethiopia and several others. The facts and figures raise a lot of concerns about the security situation in most parts of Africa, the legacy that the future will inherit, the human and natural resources that are wasted and underutilized because of the unrests and high level corruption in all the countries where the IS presence is established. It is their avowed devotion to Islam and its propagation that has led to the carnages. The psychological state of the insurgents is also in doubt because the height of insensitivity and wickedness only portray the disregard for the sanctity of human lives. The attacks were politically motivated because if they were for the benefit of individuals they should not have mercilessly killed and rendered the whole region barren and less productive. It then presupposes that wherever they exist as government there can never be progress and development, but repression and oppression.

Bernard Lewis presents some of his conclusions about Islamic culture, Shari'a law, jihad, and the modern day phenomenon of terrorism in his book, Islam: The Religion and the People. He writes of jihad as a distinct "religious obligation", but suggests that "it is a pity" that people engaging in terrorist activities are not more aware of their own religion:

Muslim fighters are commanded not to kill women, children, or the aged unless they attack first; not to torture or otherwise ill-treat prisoners; to give fair warning of the opening of hostilities or their resumption after a truce; and to honor agreements. ... At no time did the classical jurists offer any approval or legitimacy to what we nowadays call terrorism. Nor indeed is there any evidence of the use of terrorism as it is practiced nowadays."

In Surah Al-Tawba, verse 29 demands Muslims to fight all those who do not believe in Islam, including Christians and Jews (People of the Book), until they pay the Jizya, a tax, with willing submission.

Fight those who believe not in Allah nor the Last Day, nor hold that forbidden which hath been forbidden by Allah and His Messenger, nor acknowledge the religion of Truth, even if they are of the People of the Book, until they pay the Jizya with willing submission, and feel themselves subdued. (Quran 9:29)

Some people have concluded from verse 9:29, that Muslims are commanded to attack all non-Muslims until they pay money, but Shaykh Jalal Abualrub writes:

These Ayat (Quranic verses) stress the necessity of fighting against the People of the Scripture, but under what conditions? We previously established the fact that the Islamic State is not permitted to attack non-Muslims who are not hostile to Islam, who do not oppress Muslims, or try to convert Muslims by force from their 
religion, or expel them from their lands, or wage war against them, or prepare for attacks against them. If any of these offenses occurs, however, Muslims are permitted to defend themselves and protect their religion. Muslims are not permitted to attack non-Muslims who signed peace pacts with them, or nonMuslims who live under the protection of the Islamic State.(Template:Source=Abualrub, Holy Wars, Crusades, Jihad)

In Surah Al-Nisa, verse 89 has been misquoted to seem that it says to slay the apostates. In actuality, it only commands Muslims to fight those who practice oppression or persecution, or attack the Muslims.

Why should ye be divided into two parties about the Hypocrites? Allah hath upset them for their (evil) deeds. Would ye guide those whom Allah hath thrown out of the Way? For those whom Allah hath thrown out of the Way, never shalt thou find the Way. They but wish that ye should reject Faith, as they do, and thus be on the same footing (as they): so take not friends from their ranks until they forsake the domain of evil in the way of God (from what is forbidden). But if they revert to [open] enmity, seize them and slay them wherever ye find them; and (in any case) take no friends or helpers from their ranks. Except those who join a group between whom and you there is a treaty (Of peace), or those who approach you with hearts restraining them from fighting you as well as fighting their own people. If God had pleased, He could have given them power over you, and they would have fought you: therefore if they withdraw from you but fight you not, and (instead) send you (guarantees of) peace, then God hath opened no way for you (to war against them). Others you will find that wish to gain your confidence as well as that of their people: every time they are sent back to temptation, they succumb thereto; if they withdraw not from you nor give you (guarantees) of peace besides restraining their hands, seize them and slay them wherever ye get them; in their case We have provided you with a clear argument against them (Quran 4:88-91)

Sufism and the Ahamadiyya sects are Islamic and they encourage pluralism. The Sufis incorporate various philosophies, theologies and religions together, like Christianity, Judaism, Paganism, Platonism, Zoroastrianism, Buddhism, Hinduism, Paganism, Sikhism. They preach religious tolerance, peace, equality, pluralism, love for all and hate for no one. The most influential scholar is Jalaluddin Muhammad Rumi promoted inter-faith harmony through his writings. He is quoted as saying he could not find God in any place of worship but in his heart.

Rumi says:

I looked for God. I went to a temple, and I didn't find him there. Then I went to a church, and I didn't find him there. And then I went to a mosque, and I didn't find him there. And then finally I looked in my heart, and there he was.

Rumi also says: 
How many paths are there to God? There are as many paths to God as there are souls on the Earth.

Rumi also says:

A true Lover doesn't follow any one religion, be sure of that. Since in the religion of Love, there is no irreverence or faith. When in Love, body, mind, heart and soul don't even exist. Become this, fall in Love, and you will not be separated again.

The harmlessness of the claims of Sufism may be appealing to a postmodern religionist whose interest is pluralism and a peaceful coexistence, however, on a closer examination the Christian has been instructed not to compromise the unparalleled salvation in Jesus Christ. Christ taught His disciples to love and demonstrate righteous deeds without discrimination as implied in the story of the Good Samaritan; this is different from sexual love with unbelievers, in which the Christian is forbidden to engage. 2 Corinthians $6: 14-16$

You are not the same as those people who don't believe. So don't join yourselves to them. Good and bad don't belong together. Light and darkness cannot have fellowship (sharing). How can Christ and Belial (the devil) have any agreement? What can a believer have together with a non-believer? God's temple cannot have any agreement with idols. And we are the temple of the living God.

The Ahmadiyyah Islamic sect is equally Islamic and claims that all founders of religions have brought a message from 124,000 prophets because every nation at a point in history has been sent a spiritual guide by God.

Mirza Ghulam Ahmad, founder of the Ahmadiyya Muslim Community wrote in his book A Message of Peace: "Our God has never discriminated between one people and another. This is illustrated by the fact that all the potentials and capabilities (Prophets) which have been granted to the Aryans (Hindus) have also been granted to the races inhabiting Arabia, Persia, Syria, China, Japan, Europe and America."

While some Islamic sects encourage peaceful co-existence, the present wave of terrorism suggests that many more may be intolerant jihadists who seek to self-impose and not necessarily defend the cause of humanity. The obvious fact is that the radical variant of Islam that considers the tolerant Muslim as apostates can never co-exist with democracy and respect of human rights.

\section{Satanism in the Educational System}

The United States of America recently had to grapple with the demand that Satanism be accorded recognition as after school club (Rick Anderson Oct 19, 2016, Los Angeles Times); (Kathrine Stewart 30 July 2016, The Washington Post); (Rowena Lindsay Oct 19, 2016, Christian Monitor). That it is a religion and in a democratic society it should have equal rights as other religious 
International Journal of Culture and Religious Studies

Vol. 2, Issue No. 1, pp 45- 78, 2021

$\underline{\text { www.carijournals.org }}$

practices is creating a norm that could destroy that could completely topple the social order. The Editors of Encyclopedia Britannica used the expression devil worship as alternate title for Satanism described as

any of various religious or countercultural practices and movements centred on the figure of Satan, the Devil, regarded in Christianity and Judaism as the embodiment of absolute evil. Historical Satanism, also called devil worship of the JudeoChristian Devil and the explicit rejection of his antithesis, God, and (in Christianity) God's Incarnation, Jesus Christ. It was traditionally based on the "black mass", a corrupted rendition of the Christian Eucharist, and ritual magic evocations of Satan. Some more recent forms of spiritual or theistic Satanism recognize Satan as an independent non-Judeo-Christian deity. Other modern satanic movements, including the $U>S>-$ based Church of Satan (founded 1966), celebrate Satan not as god but as a symbol of supposedly anti-Christian moral values or as a pre-Christian moral values or as a pre-Christian life principle. Such movements may be theistic, agnostic or deistic.

From the foregoing definition, Satanism opposes the very foundation of Christianity. It has been observed that they do not evil in the literal sense, but they promote extreme forms of individualism, which encourages personal peace, happiness over the community. The key point in the definition submitted by Encyclopedia Britannica is that Satanism is vehemently opposed to Christianity and Judaism and the God's incarnation, Jesus Christ. That Satanism is considered as evil in the Bible is undeniable, and that is a deity that pitches its operations and interests against the God of the Bible is also very clearly expressed in it. Wikipedia defines Satanism as a group of ideologies and philosophies based on Satan. Encyclopedia Britannica also included in its submission that satanic cults existed as far back as the $17^{\text {th }}$ century and Roman Catholic Church in Europe carried out a clampdown on witchcraft, which has been recognized as a product of Satanism just like the heretics, the Gnostics, the occult and groups that subscribe to the dualistic Manichaean doctrines.

In modern times, in the 1960s Anton Lavey started the public official worship of Satan in the USA, where the democratic administration allows equal rights of worship. The forms of Satanism are categorized into theistic Satanism that venerates as a supernatural deity/god while atheistic Satanism regards Satan as a symbol of certain human traits. The contemporary trends gravitate towards identifying Satanism as an ideology and a philosophical concept espoused to denounce the hegemony of Christianity, which Satanists claim has been imposed on them. The supernatural form of Satanism is identified in occultism, witchcraft, black mass, devil worship, human sacrifice, holding mass on the back of a naked woman and other very secretive acts. However the abstract of the police training document titled "Satanic Beliefs, Criminal Actions" based on the investigation how the beliefs and practices of Satanist might be associated with criminality. The document highlights that little criminality has been linked to organized Church of Satan, Church 
of Satanic Liberation, and the Temple of Set. On another hand according to the U.S Police training document the culpable group are the Experimentalists.

"Experimentalists" are defined as youths who dabble in Satanism and drugs coupled with suggestive heavy metal music, horror videos, and fantasy role-play games. Criminal activities traced to such experimentalists have included trespass, burglary, criminal damage, drug use, homicide, and suicide. Suicide is a significant problem often associated with written pacts with the devil. A "selfstyled Satanist" is a sociopath, psychopath, or drug addict who justifies criminal acts through a belief system centered in Satan. Groups in this category include outlaw motorcycle gangs, extremist groups, drug-dealing organizations, prison inmates, and serial killers. A "satanic cult" is a relatively cohesive group of persons, akin to "self-styled Satanists," who subscribe to the perpetration of evil in a variety of ways. These cults are often composed of persons with severe mental and behavioral problems who are attracted to Satanism because it condones and encourages antisocial and deviant behavior. "Orthodox satanic groups" are intergenerational as they pass their belief systems, rituals, and coven structure from one generation to the next. Criminal acts attributed to these groups range from kidnapping and drug dealing to ritual child abuse, human sacrifice, and cannibalism.

The above reasons appear sufficient to proscribe any organization that goes by the name Satanism, but the commitment of the USA to foster peace and progress through democracy is demonstrated as being more overriding. If there are concerns to prevent intergenerational occurrence then it is a phenomenon the Government might summarily dismiss, but which it cannot because of the political policy. Even the better organized groups with little criminality are founded on the willful desire to negate, deliberately hate, denounce and antagonize the concept of God for the benefit of Satan worship creates more personality problems for young people, who without being trained in the absolute goodness of the Christian God might not be able to identify between good and evil and to make wholesome choices. Steve Rose (2015) reporting for Guardian.com wrote:

Where the city Council of Phoenix Arizona, began its meetings with a Christian prayer, for example, the Satanic temple, demanded that satanic prayers should also be said. The Council chose to drop the prayers altogether. When the child Evangelism Fellowship set up the pro-Christian Good News clubs in US public schools, the Satanic Temple introduced its own After School Satan clubspromoting scientific rationalism. And when the Oklahoma state capital permitted the installation of a Ten Commandment sculpture in its ground, the Satanic Temple campaigned to erect its own $8 \mathrm{ft}$ high statue of Baphomet, the got-headed, cloven-hoofed deity. 
The Satanic Temple claims equal rights of recognition and objects to defining America as a Christian nation. They confess to not being theistic, hence Satan is not supernatural and they do not sacrifice babies or serve a secret coven. The CNN report by Tricia Escobedo also presented Satanism as harmless. It is however objectionable that it cannot support and maintain a crime free life and environment as true Christianity has done in solving problems of the mind and personality. The USA plays a leading role in world politics and culture and the spillover effects is observed in other nations that have to grapple with deadly variants of such options in a nondemocratic setting.

\section{Philosophical Implications of Religious Pluralism for Christian Education}

Religious pluralism makes it mandatory to carry out critical philosophical reflections and theological thinking of how this phenomenon of diversity affects humanity. Since there is more than one theology, this study has considered some remarkable religions in our world today. If according to the definitions that have been retained that philosophy is all about wisdom, it should comprise of the daily opinions enunciated and the intellectual theories that have been developed about human experiences in order to solve problems and critically explain certain phenomena of life. It becomes pertinent to relate these two concepts and how they affect human existence. In the long run the hearts of individuals are the vital elements in making decisions about what to believe or not to believe. Therefore Christian Education should target nurturing the thought life of learners but should not undermine the importance of the overt display of self-discipline, purity, holiness and distinct life of love and empathy as taught by the Bible.

There is no doubt that the goodwill to co-exist peacefully has led to the theorization about pluralism and that some people accept that there are some useful elements in other religions. Pluralism becomes an essential policy and practice in a multi-religious setting in which many religious beliefs influence peoples' thoughts and attitudes. When many religions co-exist the questions that may preoccupy the philosopher are: which is the dominant religion and how does it affect the minority? How does it impact on the mental health of the society? Does it propose a good moral legacy for future generation? Does it promote fairness and justice? Does it capture the well-being of every citizen? How does it contribute to development? The pernicious effect of the proliferation of religions and sects and questionable philosophies call for an evaluation of their functionality. The Bible scholar must consider these queries in the purview of the practicality of the life changing stance and purpose of the Scripture. There are also psychological implications in which the adherents of the less favored religion tend to impose themselves in order to assert their rights therefore breeding hatred, distrust and violence in the situation. This must have been the case at the inception of Islam which had a minority followership until the Jihads and the conquest of some Middle East countries.

For each religion, pluralism is a challenge to its tenets, its widely held views and in fact the very foundation of the religion or its philosophy. For instance, if the Christendom suddenly approves pluralism as a philosophical position because of terrorism and the dangers that religious oppositions present, it means there is no difference between Christianity and other religions; every one of them becomes valid in relation to the message of Christ. The implications are far reaching 
such that within the Christian fold lukewarm lifestyle will become more pronounced with a lot of compromises. Meanwhile those who claim that all roads lead to God as they do to a market place constitute a mixed multitude and are in conflict with those whose faith is solidly entrenched in the doctrine that Jesus Christ is the only way. It is self-contradicting to claim to be a Christian and believe that there are other ways that are different from the revelation received in Christ.

For instance, the purpose and operations of African Traditional Religions (ATR) are diametrically opposed to the Christian faith. Sacrifices are daily offered in ATR and the idea of idol worship negates the concept of the unitary God of Christianity. How would a Christian live with the thought that a fellow human being is killed to replace another or is made mad on account of his or her personal well-being? These are main factors in ATR. The concept of ori in Yoruba philosophy for instance is tantamount to a violation of human rights at some point, because of the possibility that a consensus of a select people could make or mar someone and thereafter conclude it is the person's ori (head) that has rejected progress despite his or her assiduity. Meanwhile if everybody had equal chance to succeed the story would be different. At the inception of the call of the Israelites out of Egypt, families had equal share of land portions because no one was meant to be impoverished. So the notion of destiny did not exist as it is peddled today by African traditionalist and some indigenous Christians who do not wish to discard the concept as unbiblical because it is a comfortable explanation for the disparity and inequalities that have been artificially created by inequitable distribution of communal resources.

A close study of the Bible reveals that God cares for each person and that is not at the expense of anyone else because Jesus Christ God's incarnate who laid an example of God's love and equality. Part of the African Traditional Religion is aajo a Yoruba term which implies the practice of rituals to get wealthy or be successful or to solve problems like bareness or diseases, sometimes require human or animal sacrifices and the desperate seeker might need to use human parts or some animals that might not be readily available, hence, difficult and harmful means are used to procure the good and beneficial destiny when some others have. It is a grave sin to use fellow humans to meet one's own needs, which is implied in the belief that someone's destiny can be thwarted or truncated and that it takes the destruction of one person for another to be elevated. Meanwhile, God's purpose in Christ is that all persons might be saved; no one is left out in God's plan for salvation or for abundant life (John 10:10).

Religious pluralism dilutes and adulterates an individual's commitment to any particular religion, when an individual chooses to practice and believe in all existing religions. It is needful to sift opinions to arrive at one's choice; this is a solid foundation. Paul wrote to Timothy to avoid vain philosophies and arguments yet He should study the Scripture in order to correctly interpret it (2 Timothy 2:15-16). The multiplicity of religions creates problems for the society and peace within it because the moralities of religions defer. This could lead to clashes as there have been between idol worshipers or Muslims within some communities. In a larger sense it is the whole world that is under the threat of Islam, whose practices are different from the authentic Christian doctrine, though other religions may find it adaptable. The fact that some Christians or some other religionists adopt syncretism as a compromise does not seem to allay the fear of an impending genocide or war. Meanwhile, it poses a problem that the national constitutions and peace of some 
countries like Nigeria and other African nations or the Middle East are being challenged by religious mutinies. Yet it is important to reflect on one's commitment. Evans and Manis concede that:

It seems that, in a particular culture, it is almost impossible not to reflect critically on where one should place one's trust. And even if it is possible to make a commitment apart from critical reflection, the existence of even one Jonestown horror would make it clear that it is irresponsible not to exercise critical judgment when asked for commitment. (p 26)

The Jonestown horror referred to is the poisoning of some thousands of followers by Reverend Moon. Postmodern religious practice should encourage the individual to look closely into the rationale his/her beliefs. Though the assumption is that pluralism encourages tolerance, but any meaningful commitment to a faith will not approve it as an option wherein it implies equality of all religions. John Stott (1995) has this to say to Christians:

A respectful acceptance of the diversity of cultures does not imply an equal acceptance of the diversity of religions. The richness of each particular culture should be appreciated, but not the idolatry which may lie at its heart. For we cannot tolerate any rivals to Jesus Christ, believing as we do that God has spoken fully and finally through him, and that he is the only Saviour, who died, and rose again, and will one day come to be the world's Judge. (p 350)

It is mandatory therefore that each religion should define and assess its ontological commitments which, implies that believers of such religions should define the reality of God in their claims and daily existence, this is often a personal experience, which is what philosophy of religion prescribes as a starting point to finding solution to the problems caused by religious diversity. Philosophy of religion in encouraging the ontological thinking entails that the religionist should develop conviction about his/her conception rather than expect that other faiths will necessarily accept his/her views. Evans and Manis state:

Ontological arguments attempt to show that the very concept or idea of God implies his reality: that is, that one's being able to clearly conceive of God somehow implies that God actually exists. (p 63)

This ontological position means that God can be worshipped in a meaningful way and with deep conviction that He is real. Experiences tell us that all the religions do not teach the same doctrines as claimed by the Dalai Lama, but his affirmation of the incompatibility of religions is very true, but that does not exclude peaceful co-existence and good neighbourliness. Part of his speech culled from Wikipedia is again cited below for emphasis:

I am Buddhist. Therefore, Buddhism is the only truth for me, the only religion. To my Christian friend, Christianity is the only truth, the only religion. To my Muslim friend, [Islam] is the only truth, 
the only religion. In the meantime, I respect and admire my Christian friend and my Muslim friend. If by unifying you mean mixing, that is impossible; useless.

In a state of intolerance, when people are forced to accept a religion or an ideological position against their wishes they most often do not change, sometimes they choose to die for their faith and at other times they are killed in suicide bombings. The peaceful way in a multi-religious state is to make religion a private matter as its relevance in the public sphere may be the exemplified respect for human rights, empathy for others, fruit of righteousness and holy living that faith works in Believers. The Constitution of a democratic society provides the standard of living that obligates everyone to live within a restrictive code of conduct that is of benefit to all and sundry. Therein lays the basis of national growth and human development. The following observation by John Stott is quite useful for the Christian, who wants to think through his/her faith:

Both the pluralism which seeks to preserve all religions each in its own integrity, and the syncretism which prefers to blend them, deny the uniqueness and the finality of Jesus. (p 159)

The Christian should not want to preserve and subscribe to spiritual wickedness being perpetrated in the name of religion, killings, nepotism, ethnic cleansing, inequalities, gender discrimination and oppressions, he or she has therefore been called to evangelise and reach out in love to those people, who reject the claims of the Lord Jesus Christ.

\section{Conclusion}

\section{Educating Christians on tolerance}

Though Christians might appear the victims of intolerance as reported in news items, their active social and political participation may eventually yield results. The Christian attitude should be conciliatory without compromising his/her faith. It is possible to live in harmony by respectfully obeying the Constitutional law of the country where they are found. However, if it is a hostile country to Christianity, a foreign Christian can consider leaving the place for another. Unfortunately, national Christians have a lot to contend with and only God can deliver them from their oppressors and torturers. International Communities have often intervened and arbitrated in cases of individuals that have been targeted and sorely persecuted. A very remarkable example was that of Richard Wurmbrand, a Romanian pastor, who was tortured by the Nazis for being a pastor and for preaching to convert people to Jesus Christ. He narrated his devastating, horrifying and nightmarish experiences in the book Tortured for Christ.

The Christian has to live with the notion that persecution is inherent in the Christian faith because Jesus predicted it in Matthew 10: 22-23

And you will be hated by all for My name's sake, but he who perseveres and endures to the end will be saved [from spiritual disease and death in the world to come]. When they persecute you in one town [that is pursue you in a manner that would injure and cause you to suffer because of your belief], flee to another town; 
for truly I tell you, you will not have gone through all the towns of Israel before the Son of Man comes.

From this teaching the Christian should never engage in reprisals. Nowadays, the persecution of Christians gets so bad that they have to take up arms to defend themselves in some places. For example in the northern parts of Nigeria, where the Islamic terrorist group Boko Haram is on rampage, sometimes some youths (who might not be Christians) have engaged in a counterattack but they are no match for the dissidents who have sophisticated weapons.

Christian Religious Studies should emphasize peaceful coexistence because that should be the essence of any religion within a multi-religious community. While the Christian must not compromise his or her faith it is essential to know what others believe in order to reach out to them more meaningfully. Sometimes some people hold tenaciously and aggressively to beliefs that do not concede to development and progress, but allow the destruction of lives and properties in the name of religion. Christians should stay off when there is intolerance. The drive for professional success and ascent should not cause anyone to lose his or her faith in the Lord Jesus Christ. School curricula for all levels from primary to the tertiary should include as compulsory teaching on how to relate to those of other faiths. It is good for learners to know that there are many religions in the world, the components of each and how they might affect Christianity and coexistence with other faiths.

Human rationalization has proposed intermarriage among adherents of different religions. Good as that may sound but the God of the Bible forbids unequal yoke as mentioned earlier. While some have testified to the success of such interreligious unions for others the story is different. The reality is that if both parties are serious about their faith they must recognize and accept limits that are imposed by such. In the long run, it must be stated vehemently that no religion should be allowed by any national constitution or government to dominate other religions or to kill them in the name of a deity that they have never seen and whose existence they cannot empirically prove. John, a disciple of Jesus Christ polemicised :

If anyone says, I love God, and hates (detests, abominates) his brother [in Christ], he is a liar; for he who does not love his brother, whom he has seen, cannot love God, Whom he has not seen.

This appears a pragmatic way of dealing with the issue of discrimination because the believers in Christ are expected to love everybody as God indiscriminately loves the whole world.

Governments of secular nations in which some religions are in the minority should make it a policy to ensure their security and respect of their rights. Social and economic development will not be hampered as it is now in most third world countries where religions have caused a lot of devastations. To crown it all, tolerance is the foundation of any peaceful relationship within the home and in the larger community; it will forestall the contemporary realities in which individuals get very passionate about religious matters causing violent reprisals and suicide killings. The findings and conclusion that personal choices (philosophy) to respect human rights and maintain good interpersonal relationships, being selfless and considerate of others are higher values than religious sentiments that aim at forcefully subjecting people to tenets and laws that are of the least 
benefits to human progress and which do not necessarily reflect the nature of God, the Creator but that of an invisible personality that only forms a part of human imagination.

The research leans heavily on the claims of Jesus Christ, being a fact of history and whose lifestyle, teaching and philosophy express values that are worthy of emulation for human development, progress and peace. This is what the Christian should aim to propagate without leaving loopholes for justifiable criticism of misconduct.

\section{REFERENCES}

Amplified Bible online

Anderson, Rick. (Oct 19 2016). "Yes, An After School Satan Club Could BE Coming to Your Kid's Grade School." https://www.latimes.com/nation/la-na-satanic-after-school20160928-snap-story.html

Bahati, Linnete and Driss El-Bay. (14 June 2021). BBC Monitoring: Allied Democratic Forces: The Ugandan rebels working with IS in DR Congo. https://www.bbc.com/news/worldafrica-57246001

BBC (14 June 2021) IS Badoush prison massacre: Iraq exhumes bodies from mass grave

Daniels, S. (1989). "Satanic Beliefs, Criminal Actions.” Alexandria, USA: International Assoc. of Chiefs of Police 44 Canal Center. NCJ Number 133660 ojp.gov/ncjrs/virtuallibrary/abstracts/satanic-beliefs-criminal. Accessed 21 June 2021.

Dr Ewelina U. Ochab, who reported in Forbes (https://www.forbes.com>2021/05/05)

Editors of Encyclopedia Britannica. Satanism (occult practice). www.britannica.com/topic/Satanism. Accessed 26 June 2021.

Enos, Olivia (May 12 ${ }^{\text {th }}, 2021$ ). "Religious Persecution In China Intensifies With Brainwashing Camps For Christians." www.heritage.org/religious-liberty/commentry/religious. Accessed 23 June 2021

Evans S. G. \& Manis, Z. R. (2009). Philosophy of Religion. Downers Grove, Illinois:. Intervarsity Press.

Gardner, Frank (3 December 2020) Is Africa overtaking the Middle East as the new jihadist battleground? https://www.bbc.com/news/world-africa-55147863.Accessed 24 June 2021.

Holocaust Encyclopedia. “Antisemitism in History: Racial Antisemitism, 1875-1945" Accessed 22 June 2021.

https://www.bbc.com/news/world-middle-east-57468594 Accessed 24 June 2021

Kuo, Lily. (13 Jan 2019) "In China, they're closing churches, jailing pastors - and even rewriting scripture" www.theguardian.com/world/ 
International Journal of Culture and Religious Studies

Vol. 2, Issue No. 1, pp 45- 78, 2021

Www.carijournals.org

Lewis, Bernard and Buntzie Ellis Churchill. (2009), Islam: The Religion and the People. New Jersey: Person Educational Inc.

Lindsay, Rowena (Oct 19 2019). Should Satanists Be Allowed to Run After School Club in Public Schools? https://www.csmonitor.com/USA/2016/1019/Should-satanists-be-allowed-torun-after-school-clubs-in-public-schools

Ma, Alexandra. (https://www.businessinsider.com>how-xi-jinping-is-attacking-religion-inchina)

Macquarrie, J. (1998). In SPCK Handbook of Anglican Theologians. Ed Alistair McGrath, 1998

Mark, Joshua J. (22 February, 2011). Mesopotamian Religion. World History Encyclopedia. www.worldhistory.org/Mesopotamian_Religion/ Accessed 20 June 2021.

Murad Batal al-Shishani. A History of Modern Jihadism (11 December 2014) https://www.bbc.com/news/world-middle-east-30436486

Myers, David G. (2010) Social Psychology. New York : McGraw-Hill.

Omoregbe, J. (1993). A Philosophical Look at Religion. Lagos. Joja Educational Research and Publishers Ltd.

Paveley, Rebecca. (19 February, 2021) in the article titled "Persecution of Christians Predicted to Worsen in China" https://www.churchtimes.co.uk>news

Popkin H. R.; Stroll A. \& Kelly A. V. (1993). Philosophy Made Simple. London: Routledge.

Religious Pluralism. Internet Encyclopedia of Philosophy.

Soboyejo, J. O. (2018). Lecture notes on Philosophy of Religion at the Crowther Graduate Seminary, Abeokuta.

Stewart, Katherine (30 July 2016). "An After School Satan Club Could Be Coming to Your Kid's Elementary School." https://www.washingtonpost.com/local/education/an-after-schoolsatan-club-could-be-coming-to-your-kids-elementary-school/2016/07/30/63f485e65427-11e6-88eb-7dda4e2f2aec_story.html

Stott, John. Authentic Christianity. (1995). Downers Grove, Illinois: Inter-Varsity Press.

Template : Cite Hathout, Jihad vs. Terrorism; US Multimedia Vera International, 2002, pp.52-53

The Heritage Foundation. (May 14 2019). "Religious Freedom: What is at Stake If We Lose It." www.heritage.org/religious-liberty/commentary/religious-freedom-whats-at-stake-if-welose-it

United Nations Report of the Office of the United Nations High Commissioner for Human Rights on the human rights situation in Iraq in the... (2015). (https://digitallibrary.un.org/record/791021?ln=en) Accessed 26 June 2021.

VenusFeuerFalle (ed). February (2021) Islam and Other Religions. https://en.m.wikipedia.org>wiki> Accessed 24 April 2021 
International Journal of Culture and Religious Studies

Vol. 2, Issue No. 1, pp 45- 78, 2021

www.carijournals.org

Voice of the Martyrs (persecution.com/global>china)

Wikipedia, Islam. https://en.m.wikipedia.org>wiki>Islam. Accessed 9 September, 2019.

World Atlas. www.worldatlas.com/articles/sinicization

Wotogbe-Weneka, W. O. "Religion: Modern Denigration and Rehabilitation in National Development" An Inaugural Lecture in the Department of Religious Studies \& Cultural Studies. Faculty of Humanities.

www.opendoors.org.za/christin-persecution/christian-persecution-today 